\title{
FINANCIAL VALUE OF MOSSURIZE FOREST IN MOZAMBIQUE
}

\author{
Felita Joaquim Júlio ${ }^{1}$, Mario Paulo Falcão ${ }^{2}$, Romano Timofeiczyk Junior ${ }^{3}$, David Alexandre Buratto ${ }^{4}$, \\ Amarildo Hersen ${ }^{5}$ \begin{abstract}
${ }^{2}$ University Eduardo Mondlane, Department of Forestry Engineering, Maputo, Mozambique - mariopaulofalcao@ hotmail.com 3University of Paraná, Department of Rural Economy and Extension, Curitiba, Paraná, Brazil - romano.timo@ gmail.com ${ }^{5}$ University of Paraná, Graduate Program in Forest Engineering, Curitiba, Paraná, Brazil - amarildohersen@ yahoo.com.br
\end{abstract} \\ ${ }^{1}$ UniversityEduardo Mondlane, Department of Agrarian Economics, Maputo, Mozambique - fjoaquim@gmail.com \\ 4 *Federal University of Paraná, Graduate Program in Forest Engineering, Curitiba, Paraná, Brazil - davidburatto@ gmail.com *
}

Received for publication: 30/06/2017 - Accepted for publication: 10/05/2019

\begin{abstract}
Resumo
Valor financeiro madereiro da floresta de Mossurize em Moçambique. A floresta de Mossurize ainda não possui um valor financeiro e para tanto há a necessidade de estimar e quantifica-lo, pois tal procedimento proporcionará a referência financeira da mesma, estimulando assim fontes alternativas de renda para as comunidades rurais e preocupação com utilização de práticas sustentáveis no uso dos recursos florestais. O objetivo deste trabalho foi calcular o valor financeiro da floresta de Mossurize, província de Manica, República de Moçambique, com a identificação do valor dos produtos florestais e desta forma fornecer subsídio econômico para a exploração racional de seus recursos. Este trabalho foi desenvolvido em uma área de 41.331 hectares. Para caracterizar a cobertura vegetal recorreu-se aos dados de inventário das espécies arbóreas. A metodologia de cálculo, por amostragem, fez uso de procedimentos de quantificação das espécies com valor comercial, Corte Anual Admissível (CAA), Custo Unitário e Anual, Receita total, Benefício Líquido (BL) e Valor Presente Líquido (VPL). Os resultados indicam um valor financeiro positivo para esse processo florestal, considerando-se o valor comercial das espécies. Salienta-se a necessidade de criação e melhoramento de programa de manejo sustentável para a floresta e estímulo de mercado para os produtos do manejo sustentável. Palavras-chave: Floresta de miombo, produto madeireiro, Valor Presente Líquido
\end{abstract}

\begin{abstract}
The Mossurize forest does not yet have a financial value and therefore there is a need to estimate and quantify it, as this procedure will provide the financial reference of the same, thus stimulating alternative sources of income for rural communities and concern with the use of sustainable. practices in the use of forest resources. The objective of this work was to calculate the financial value of the Mossurize forest, Manica province, Republic of Mozambique, with the identification of the value of forest products and thus provide economic subsidy for the rational exploitation of their resources. This work was developed in an area of 41,331 hectares. To characterize the vegetation cover was used the inventory data of the tree species. The calculation methodology, by sampling, made use of quantification procedures for the commercial value species, Annual Acceptable Cut (AAC), Unit and Annual Cost, Total Revenue, Net Benefit (NB) and Net Present Value (NPV). The results indicate a positive financial value for this forest process, considering the commercial value of the species. It is highlighted the need to create and improve a sustainable forest management program and market stimulus for sustainable management products.

Keywords: forest of miombo, timber product, net present value
\end{abstract}

\section{INTRODUCTION}

Mozambique has a population of approximately 24 million, of which more than half live below the poverty line and therefore subject to famine. Approximately $80 \%$ of the population depends directly on natural resources, which is one of the factors that most contributes to deforestation (NATIONAL INSTITUTE OF STATISTICS, 2012).

In developing countries, the continuous increase in population puts increasing pressure on forested areas to increase agricultural productivity levels, as the basis of the population's livelihoods, especially rural ones, is agriculture (MICOA , 2008; PRATES; GRACHAS, 2011).

In this regard, the region where the district of Mossurize is located, Manica province - Republic of Mozambique, has a diversity of plant species used by the population to obtain wood fuel, to expand the area for agricultural production and to exploit timber resources commercially used (JÚLIO, 2016).

However, according to Correia et al. (2009) forests, besides being economically and socially important, are considered above all, environmental wealth. The 1972 Stockholm conference recognized forests as the largest, most complex and durable of all ecosystems and emphasized the need for rational land and tree use policies as well as continuous monitoring of the conservation status of forests worldwide and introduction of forest management planning. 
In this sense, the knowledge of the value of the Mossurize forest and the benefits generated through its goods and services has the potential to assist in the attribution of fair value, which can carry out an analysis of the benefits and costs for forest conservation and preservation. This assessment can be an important tool in formulating environmental policies for the rational use of natural resources.

According to Motta (1998), despite the existence of a value for environmental goods such as forests, there are still many products whose value is unknown. Ignorance of value induces the irrational use of products, generating excessive use of resources by rural and business communities, preventing markets for forest products in this region from being created and standardized.

Given that the Mossurize forest does not have an estimated financial value yet, it is necessary to identify the species existing in the forest and the species with commercial value. The importance of estimating the financial value of the forest should be highlighted, as it provides the financial reference of the forest, thus stimulating alternative sources of income for rural communities and concern with the use of sustainable practices in the use of forest resources.

Against this background, Mozambique faces a major environmental challenge of increasing the preservation level of forested areas in view of the high poverty rates of a population that lives directly from forest resources. For this, determining the financial value of a forest is a way of monetarily valuing the environmental resources present in it (JÚLIO, 2016). It should be noted, however, that this work did not consider environmental services, biodiversity and other forest uses, such as tourism and biomass carbon value. Only the extraction of timber products.

In an effort to identify the value of Mossurize forest products and thus provide economic support for the rational exploitation of its resources, this work aimed to estimate the financial value of the above forest through the following specific objectives: (a) quantify species of commercial value; (b) determine the financial value of timber products.

\section{MATERIAL AND METHODS}

\section{Material}

\section{Characterization of the study area}

This work was developed on an area of 41,331 hectares, located in Mossurize district, Manica province Republic of Mozambique (Figure 1). According to Ferro and Bouman (1987), the climate of the district of Mossurize, according to the Köppenclassification, is of humid temperate type. The average annual rainfall is about $1,501 \mathrm{~mm}$ according to data from Espungabera weather station and the rainy season occurs mainly from October to April with the highest rainfall from December to March.

The average annual evapotranspiration is about $1,170 \mathrm{~mm}$. Average temperatures range around $20^{\circ} \mathrm{C}$, with a maximum average of $25^{\circ} \mathrm{C}$ and a minimum average of $15.1^{\circ} \mathrm{C}$. It has a normal period of growth, with a dry period of 95 days, an intermediate period of 120 days - between the dry and wet period - and a wet period that extends for 150 days. The wet season begins in the first half of November and ends in the first half of April (MINISTRY OF STATE ADMINISTRATION, 2005).

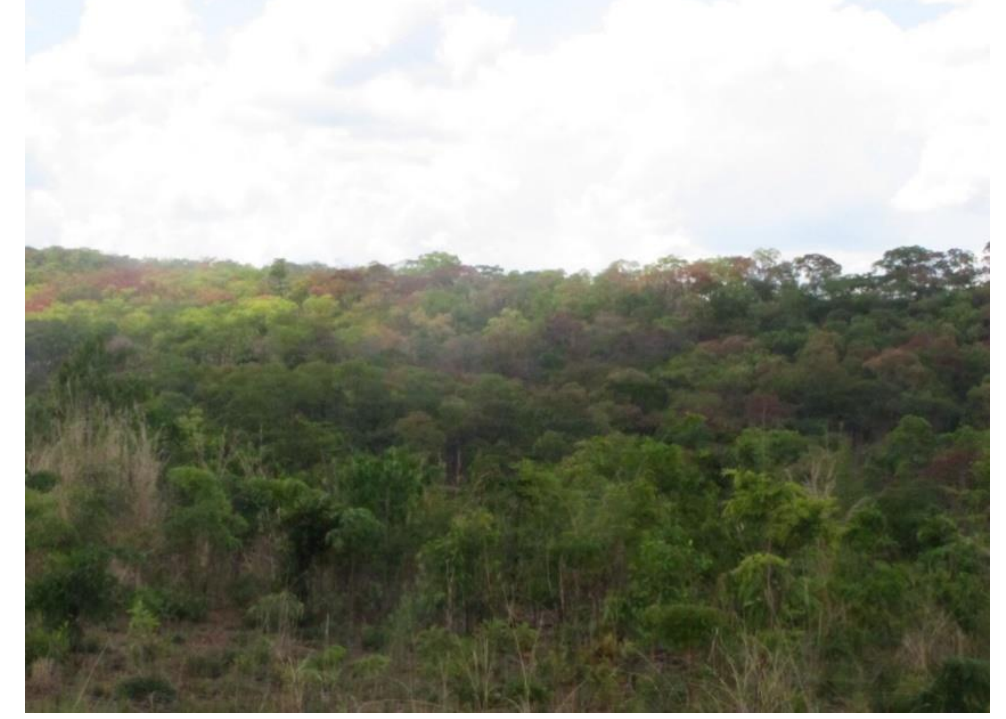

Figure 1. Miombo Forest in Mossurize.

Figure 1. Miombo forest in Mussorize. 


\section{Sampling Method}

The stratified random sampling method was used, in which the number of plots was randomly selected over a systematic grid of points (regular square grid with a mesh of $250 \mathrm{~m}$ and North-South and East-West orientation) with random origin and covering the entire eligible area of the 41,331 ha of the study area. The calculation of the minimum amount of plots to ensure a sampling error of less than $20 \%$ was obtained based on forest inventories from neighboring areas and 135 plots of 0.13 ha size were defined (VIANNA, et al., 2010, HIGA, et al., 2014).

\section{Vegetation cover characterization}

In order to characterize the vegetation cover, the inventory data were used, and the existing species and their dendrometric data were surveyed. Absolute abundance, relative abundance, dominance, frequency and importance value index were used to identify the most important species in the Mossurize forest. In each plot, homogeneous spot coverage was measured. Forest cover resulted from the ratio of the horizontal projection area of the tree tops to the land area (HIGA, et al., 2014).

\section{Methods}

\section{Quantification of species of commercial value}

To quantify commercial species, firstly, they were identified where they were grouped into four classes, namely: precious, 1st class (high commercial value and mainly intended for export to the Asian market), 2nd class (intended for domestic consumption) and 3rd class (biofuel, such as firewood and coal). Then, the maximum volume of cut for each species, also called Annual Allowable Cut (CAA), formulated by Saket (1994), was determined, being the methodology used in Mozambique.

CAA is the volume of wood that can be extracted annually from the forest without jeopardizing the sustainability of the resource and to be calculated it was necessary to know the standing commercial volumes of each commercial species and the timber cutting cycle.

The calculation of the annual allowable cut was given by (JÚLIO, 2016):

$$
C A A=\frac{V_{1}+S P_{1}+f_{1}}{n}+\frac{V_{2}+S P_{2}+f_{2}}{n}+\frac{V_{3}+S P_{3}+f_{3}}{n}
$$

where: CAA the Annual Allowable Cut ( $\mathrm{m}^{3} /$ year), $\mathrm{SP}_{1}$ the forest-type productive forest area $10-30 \%$ (ha), $\mathrm{SP}_{2}$ the forest-type productive forest area 30-40\% (ha), $\mathrm{SP}_{3}$ the forest area forest type $40-50 \%$ (ha), $\mathrm{V}_{1}$ the standing volume ( $\left.\mathrm{m}^{3} / \mathrm{ha}\right), \mathrm{V}_{2}$ the standing volume $\left(\mathrm{m}^{3} / \mathrm{ha}\right), \mathrm{V}_{3}$ the standing volume $\left(\mathrm{m}^{3} / \mathrm{ha}\right)$, in the cycle (number of years, which conventionally in the country is defined from 20 to 30 years, depending on growth) and $f_{\mathrm{n}}$ the safety factor to ensure forest regeneration of commercial species $(1=10-30 \%$ of forest cover; $2=30-40 \%$ forest cover, $3=40$ $50 \%$ forest cover). This is due to the fact that with less forest cover, there is less competition and it is possible to remove more wood (larger trees).

The safety factor represents the amount of mature trees that must be left undeveloped to serve as seed producers and to ensure natural regeneration. For less abundant commercial species such as Sclerocarya birrea, Erythrophleum suaveolens, Afzelia quanzensis, Pterocarpus angolensis, Khaya nyasica (respectively: Canho, Missanda, Chanfuta, Umbila and Umbaua) $30 \%$ was used as safety factor and $20 \%$ for other species. most common - management plan of the Technical Institute of Mozambique - ITM.

\section{Cost Determination}

For the present study we considered the costs related to the forest inventory and the management plan, which are performed every five years. Exploration that is done annually includes felling, delimbing and transportation. Costs per cubic meter were converted into annual costs through Equation (4) as proposed by Julius (2016):

$$
C a=C u \times V
$$

where: $\mathrm{Ca}$ is the annual cost (US $\$$ / year), $\mathrm{Cu}$ is the unit cost (US $\left.\$ / \mathrm{m}^{3}\right)$ and $\mathrm{V}$ is the wood volume (permissible annual cutting).

Including transportation to the market in Beira City, the annual cost was given by Equation 5, as elaborated by Julio (2016):

$$
C a=C u \times p \times V \times d
$$


where: $\mathrm{Ca}$ is the annual cost, $\rho$ the average wood density in $\operatorname{logs}\left(0.75 \mathrm{t} / \mathrm{m}^{3}\right)$, the distance between Mossurize and the city of Beira $(\mathrm{km}), \mathrm{V}$ the permissible annual cut and $\mathrm{Cu}$ the unit cost (US $\$ / \mathrm{t})$.

\section{Revenue Determination}

The revenues considered in this study were the annual sales of logs and the reimbursement of $15 \%$ of the logging fee, which is the amount the State pays the concessionaire for reforestation, in accordance with Federal Law 10. / 99. The selling price of timber in the present work varied according to the species. Annual revenue from the sale of timber of commercial species was obtained through Equation (6), according to Julius (2016):

$$
R t=\sum_{s=1}^{n} P_{s} \times V_{s}
$$

where: Rt is the total revenue (year), $\mathrm{P}_{\mathrm{s}}$ is the price of the $s$ timber species and $\mathrm{V}_{5}$ is the annual cutting volume of the species $s$

\section{Financial value}

According to Julio (2016), after determining the costs, revenues and carbon value of biomass, present in the species of commercial value in the Mossurize forest, the financial value of this forest was estimated by summing the net benefits of its assets and services (Equation 7):

$$
\begin{aligned}
& \text { Direct use }=\text { Commercial species } \\
& B L_{\text {Indirect }}=B L_{\text {Carbon sequestration }} \\
& V_{\text {floresta }}=B L_{\text {Species }}+B L_{\text {Carbon sequestration }}
\end{aligned}
$$

where: BL is the Net Benefit and $\mathrm{V}_{\text {forest }}$ the Financial Value of the forest.

It was based on the Net Present Value method, also known as NPV, as suggested by Anna and Nogueira (2010), to determine the financial value, since for goods and services that have market price one of the best ways to value is through your NPV. To obtain the revenues, the market price was used, which consisted of multiplying the quantities by their respective prices. The commercialization prices were obtained considering the classes of each species.

As it is an economic analysis in the forestry segment, it was assumed a 50-year projection (commonly used in Miombo forests) and a discount rate of $10 \%$ per year, the same used by the Mozambican financial institutions. The financial value of the species of commercial value was obtained from the NPV calculation, which is the difference between the present value of revenues minus the present value of costs. According to Silva $e t a l$. (2005) can be defined as the algebraic sum of the discounted cash flow values associated with it. From the quantification of costs (Equation 5) and revenues (Equation 6), one can estimate the financial value of the forest:

$$
V P L=\sum_{j=0}^{n} R j(1+i)^{-j}-\sum_{j=0}^{n} C J(1+i)^{-j}
$$

where: $\mathrm{Rj}$ is the revenue of the time period already considered, $\mathrm{Cj}$ is the costs of the time period already considered, the project duration in years or number of time periods and the annual interest rate, expressed in decimal form.

Adding the Net Present Value of carbon to commercial species, we obtained the financial value of the forest, according to equation 9:

$$
V P L_{\text {floresta }}=V P L_{C}+V P L_{M}
$$

where: NPV forests the Net Present Value of the Mossurize Forest, VPL $\mathrm{V}_{\mathrm{C}}$ the Net Present Value of carbon and $\mathrm{NPV}_{\mathrm{m}}$ the Net Present Value of commercial species. 


\section{RESULTS}

\section{Species of commercial value}

In the forest 18 species of commercial value were found, according to the Mozambique Forest and Wildlife Regulations (MOÇAMBIQUE, 2002). Figure 2 shows the number of species with commercial value, according to different diameter classes. Note that the largest numbers of plants were found in the diameter class of $10-19 \mathrm{~cm}$.

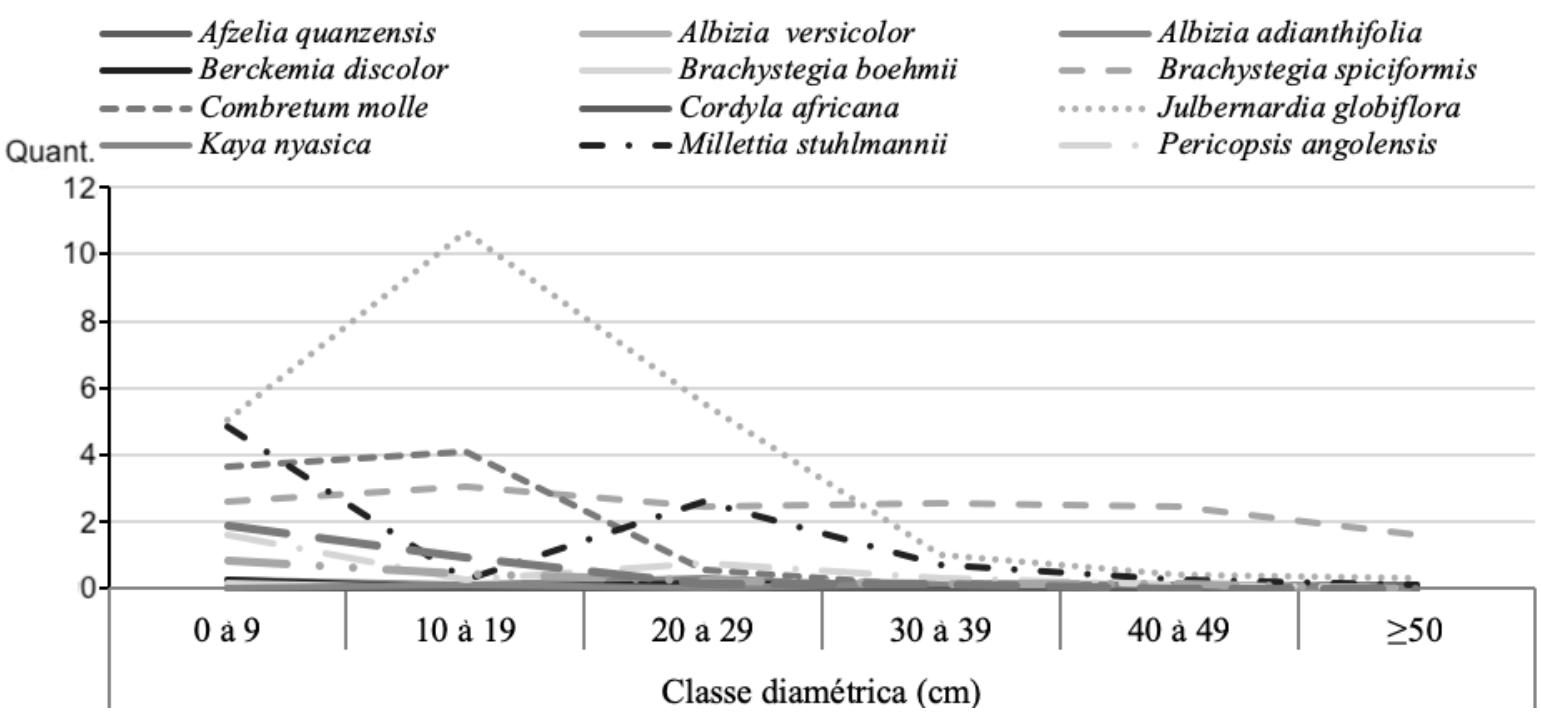

Figure 2. Number of plants per hectare of species classified as commercial in the area of a forest in Mossurize. Figure 2. Number of plants per hectare of species classified as commercial in a forest area in Mossurize.

The species with the highest CAA value were Brachystegia spiciformis, Millettia Stuhlmannii and Julbernardia globiflora ( Table 1).

Table 1. Annual Allowable Cut (CAA) by commercial species in the forest.

Table 1. Allowable Annual Cut (AAC) for commercial species in the forest.

\begin{tabular}{llll}
\hline Type & $\begin{array}{l}\text { Volume } \\
\text { measured }\left(\mathrm{m}^{3}\right)\end{array}$ & $\begin{array}{l}\text { Volume } \\
\text { unitary }\left(\mathrm{m}^{3} / \mathrm{ha}\right)\end{array}$ & CAA $(\mathrm{m} 3 /$ year $)$ \\
\hline Berckemia discolor & 0.37 & 0.02 & 38.96 \\
Swartzia madagascariensis & 0.33 & 0.02 & 34.75 \\
Kaya nyasica & 1.03 & 0.07 & 108.46 \\
Millettia stuhlmannii & 6.37 & 0.41 & 670.77 \\
Albizia versicolor & 1.00 & 0.06 & 105.30 \\
African Cordyla & 1.00 & 0.06 & 105.30 \\
Afzelia quanzensis & 1.32 & 0.08 & 121.62 \\
Pterocarpus angolensis & 1.68 & 0.11 & 154.79 \\
Albizia adianthifolia & 0.71 & 0.05 & $74-76$ \\
Brachystegia boehmii & 0.22 & 0.01 & 23.17 \\
Brachystegia spiciformis & 36.55 & 4.32 & $7,142.00$ \\
Julbernardia globiflora & 11.61 & 0.74 & $1,222.56$ \\
Pericopsis angolensis & 1.04 & 0.07 & 109.51 \\
Terminalia sericea & 5.07 & 0.32 & 533.88 \\
Acacia nigrescens & 0.38 & 0.02 & 40.02 \\
Pseudolachnostrylis maprounefolia & 3.32 & 0.21 & 349.60 \\
Strychnos madagascariensis & 0.35 & 0.02 & 36.86 \\
Xeroderris stuhlmannii & 1.64 & 0.11 & 172.70 \\
\hline Total & & 6.71 & $11,045.01$ \\
\hline & & & \\
\hline
\end{tabular}




\section{Financial value for exploitation of timber products}

The Net Present Value of Mossurize Forest was \$ 43,712,244.23. The unit cost for exploration - which includes logging, delimbing and transportation - was $\$ 68.58$ and $\$ 3.92$ per year for common costs. For the forest inventory and management plan that were carried out in the year $0,5,10,15,20,25,30,35,40,45,50$ it was $\$$ 7,290 and $\$ 3,012$, respectively. , for every five years. The exploration fee was $\$ 371,069.40$.

Table 3. Unit production costs in the Mossurize forest.

Table 3. Production unit costs in Mossurize forest.

\begin{tabular}{lll}
\hline Item & Year of occurrence & Unit cost (US \$ / year) \\
\hline Forest Inventory & $0 ; 5 ; 10 ; 15,20,25,30,35,45,50$ & $7,290.00$ \\
Handling plan & $0 ; 5 ; 10 ; 15,20,25,30,35,45,50$ & $3,012.00$ \\
Annual & costs & 68.58 \\
Annual & costs & $371,069.40$ \\
Annual common & costs & 3.92 \\
Handling & 1 to 50 years & $1,000.00$ \\
\hline
\end{tabular}

Estimated net annual revenue from wood exploitation in the Mossurize forest was US \$2,853,097.40, which corresponds to net revenue of US $\$ 60.61$ per hectare. For the precious timber class, the highest estimated annual net revenue was for the Swartziz madagascariensis species with US $\$ 20,849.78$. For the first class timber, the estimate of higher net annual revenue was with the species Millettia stuhlmannii, which reached US \$ $234,770.61$.

However, it was with second class timber that the highest annual net revenue was estimated. Brachystegia spiciformis corresponded to US \$1,785,499.20, over $62 \%$ of the total and Jubernardia globiflora US \$305,638.80, equivalent to $10.71 \%$ of the total. Finally, for class 3 , the highest estimated annual net revenue was for Terminalia sericea with $\$ 133,470.17$ (Table 4).

Table 4. Annual net revenue for each commercial species.

Table 4. Annual revenue for each commercial species.

\begin{tabular}{llll}
\hline Type & Price (US\$) & Revenue (US \$ / year) & Revenue (\%) \\
\hline Berckemia discolor & 250.00 & $9,740.43$ & 0.34 \\
Swartziamadagascariensis & 600.00 & $20,849.78$ & 0.73 \\
Kaya nyasica & 250.00 & $27,115.24$ & 0.95 \\
Millettiastuhlmannii & 350.00 & $234,770.61$ & 8.23 \\
Albizia versicolor & 250.00 & $26,325.48$ & 0.92 \\
African Cordyla & 250.00 & $26,325.48$ & 0.92 \\
Afzelia quanzensis & 290.00 & $35,270.88$ & 1.24 \\
Pterocarpus angolensis & 300.00 & $46,438.14$ & 1.63 \\
Albizia adianthifolia & 250.00 & $18,691.09$ & 0.66 \\
Brachystegia boehmii & 250.00 & $5,791.61$ & 0.20 \\
Brachystegia spiciformis & 250.00 & $1,785,499.20$ & 62,58 \\
Julbernardia globiflora & 250.00 & $305,638.80$ & 10.71 \\
Pericopsis angolensis & 250.00 & $27,378.50$ & 0.96 \\
Terminalia sericea & 250.00 & $133,470.17$ & 4.68 \\
Acacia nigrescens & 250.00 & $10,003.68$ & 0.35 \\
Pseudolachnostrylis maprounefolia & 250.00 & $87,400.59$ & 3.06 \\
Strychnos madagascariensis & 250.00 & $9,213.92$ & 0.32 \\
Xeroderris stuhlmannii & 250.00 & $43,173.78$ & 1.51 \\
\hline
\end{tabular}




\section{Discussions}

\section{Species of commercial value}

Miombo forests are not considered rich in terms of species of commercial value and also because of the use of communities for the production of wood fuels. Brachystegia spiciformis, besides having several plants with a diameter class of $10-19 \mathrm{~cm}$, has a larger number of plants in the subsequent classes than the others, which can be explained by the fact that it was one of the most abundant species in the Mossurize forest.

The Mossurize Forest presented an Annual Allowable Cut (CAA) of $11,045.01 \mathrm{~m}^{3} /$ year. This value occurred mainly because it was a degraded forest. The allowed volume of annual logging is reduced because this type of forest is the one that has suffered the most deforestation in recent times. Of the $270,000 \mathrm{~m} 3$ of wood harvested per year, 90 to $95 \%$ corresponds to 10 commercial species, which leads to a small number of high value trees to supply the entire commercial species market.

\section{Financial value for exploitation of timber products}

Several studies on the value of the forest obtained relatively high values compared to the present study, because they included other goods and services produced by the forests. The existence of a financial value for the Mossurize forest reinforces the value of the standing forest, taking into account the amount of carbon accumulated and the commercial value of the species. Since it is a natural resource, this value from the economic point of view of natural resource valuation represents an instrument for cost / benefit analysis of keeping the forest upright.

The species in Table 4 can be considered important in the Mossurize forest as they contribute significantly not only to the commercial volume of the forest but also to its annual revenue. All together make up $86.9 \%$ of the total annual revenue of commercial species.

The Net Present Value of timber products in the Mossurize Forest was \$23,858,973.89, or \$ 577.26 per hectare. When compared to other studies such as Ghani (2006) who found 321.21US \$ / ha in Malaysian forest ecosystems, the NPV for timber products from the Mossurize forest is considered high.

\section{CONCLUSIONS}

- There are species of commercial value and economic viability in maintaining the Mossurize Forest in Mozambique, however, for the Forest to be kept upright there is a need for the prices of products resulting from sustainable management to be higher than the prices of products resulting from the forest that will be planted. Thus, the creation and improvement of two essential elements is indispensable: sustainable forest management program and market stimulation for sustainable management products.

- The management program, focusing on forest maintenance, should encourage sustainable management practices - comprised of several projects - which could be achieved through technical assistance work to rural communities, exploring the potential of the forest, avoiding its destruction in germ.

- The stimulation of new markets for products resulting from sustainable management could be achieved through the creation of associations and partnerships with the public and private sector in the acquisition of these products for the maintenance of, for example, schools and companies. Production resulting from sustainable management and a market with prices higher than the price of deforestation products are the essential elements for the maintenance of the Mossurize Forest.

\section{BIBLIOGRAPHIC REFERENCES}

ANNA, A; NOGUEIRA, J. Valoração Econômica dos Serviços Ambientais de Florestas Nacionais. Administração e Negócios da Amazónia Magazine, v.2, n. 1. 2010.

CORREIA, A; BAPTISTA, C; GABRIEL, C; PINHO, J; CARVALHO, M; COLAÇO, M e QUEIROS, R. Manual de Educação Florestal- Floresta, Muito mais que Arvore. ed. autoridade florestal, Lisboa, 2009.

NATIONAL INSTITUTE OF STATISTICS. Estatística e indicadores sociais 2008 - 2010.Maputo: INE, 2012. $58 \mathrm{p}$.

FERRO, B.P., \& BOUMAN, D. Hydrogeological map of Mozambique.Ministry of Construction and Water of Mozambique /UNICEF. 1987 Maputo.

GHANI, A. N. A.; OTHMAN, M. S.; MOHD, R.; MOHAMED, S.; IBRAHIM, F. H.; HUSSIN, M. Z.; NOOR, K. M.; IDRIS, M. A. M. Economic valuation and accounting of forest resources in Malaysia, Agricultural Sciences, 2016. 
HIGA, R. C. V.; CARDOSO, D. J.; ANDRADE, G. C.; ZANATTA, J. A.; ROSSI, L. M. B.; PULROLNIK, K., NOCODEMO, M. L. F.; GARRASTAZU, M. C.; VASCONCELOS, S. S.; SALIS, S. M. Protocolo de medição e estimative de biomassa e carbono florestal. Documeto Eletrônico, Colombo: Embrapa Florestas, 2014.

JÚLIO, F. J.Valor Financeiro da Floresta de Mossurize. 90 p. Dissertation (Master in Agrarian Economics) Eduardo Mondlane University, Maputo, 2016.

LESCUYER, G. Livelihoods and the adaptive application of the law in the forests of Cameroon. In L. Tacconi, ed. Illegal logging: law enforcement, livelihoods and the timber trade, pp. 167-190. London, Earthscan. 2007.

MINISTRY OF STATE ADMINISTRATION. Profile of the District of Manhiça. Maputo province. District Profiles Series, Maputo: MAE. 2005

MOZAMBIQUE Law no. July 10, 7, 1999. It establishes the basic principles and norms on the protection, utilization and sustainable conservation of forest and wildlife resources. Official Publication of the Republic of Mozambique. Mozambique, July 12 1999. Available at: http://extwprlegs1.fao.org/docs/pdf/moz20106.pdf. Accessed on: May 25, 2017.

MACHOCO, R. de S. Factor de Expansão de Biomassa Florestal na Região do Corredor da Beira. Eduardo Mondlane University. FAEF / EMU: Maputo. 2008

MICOA Report of the study assessing the interaction between biodiversity and poverty in Mozambique. Ministry for the Coordination of Environmental Action (MICOA), Maputo. 2008.

MOZAMBIQUE Bulletin of the Republic: Regulation of the Forest and Wildlife Law, 1st Series, n. $22,2002$.

MOTTA, R. S. Manual para valoração econômica de recursos ambientais. Brasília: Ministry of the Environment, Water Resources and Legal Amazon, 1998.

MOUTINHO, P.; SANTILLI, M. Submissão Internacional à UNFCC/SBSTA. UNFCC / CP / 2005 / L.2. Instituto de Pesquisa Ambiental da Amazônia 2005.

PRATES, Rodolfo; GRACHA, Carlos. Os Processos de Desenvolvimento e Desmatamento da Amazonia. Economia e Sociedade, Campinas.v. 20, n. 3(43). p.601-636, 2011.

PEARCE, D. The economic value of forest ecosystem.CSERGE-Ecomics, University College London, London UK. 2001.

REZENDE, J.L.P; OLIVEIRA, A.D. Análise econômica e social de projetos florestais. Viçosa: UFV; 2001. 389 p.

RIBEIRO,S; G, L; SOARES,C; MARTINS, S; SOUZA, A; NARDELLI A. Ajuste de equações alométricas para Araucaria Angustifolia (Bert.) O. Ktze. using principal component analysis in conjunction with regression analysis. Árvore Magazine, Viçosa, v.33, n.5, p.917-926, 2009.

SAKET, M. Report on The Updating of the Exploratory National Forest Inventory.Moçambique: DNFFB, 1994. (FAO / UNDP, MOZ / 92/013)

SILVA, M. L.; FONTES, A. A. Discussão sobre os critérios de avaliação econômica: valor presente líquido (VPL), valor anual equivalente (VAE) e valor esperado da terra (VET). Tree Magazine,Viçosa, v. 29, no. 6, p. 931-936, 2005.

VIANA, A. L. M.; VIDAL, E. J.; GORENSTEIN, M. R.; BATISTA, J. L. F. Tamanho ótimo de parcela para estimativa de estoque de carbono de parte aérea lenhosa de fitofisionomias florestais na Amazônia oriental. Floresta Magazine, Curitiba, v. 40, no. 2, p. 447-456, 2010.

WILliAMS C, A; NIALL, P. H; NEFF, J. C; SCHOLES, R. J; BERRY, J. A; DENNING, A S; BAKER, D F. Africa and the global carbon cycle. Carbon Balance and Management, London, v. 2, n. 3. 2007. 